\title{
Polish Mesolithic Pots. Jasiu Kowalczyk - in memoriam
}

\author{
Stefan Karol Kozłowski ${ }^{a}$
}

The article deals with making of pottery among the European Mesolithic communities. The author, referring to the terminological proposal of Jan Kowalczyk - "ceramic Mesolithic", follows in this respect the development of research and the evolution of views of Polish Stone Age researchers.

KEY-WORDS: Jan Kowalczyk, ceramic Mesolithic, Neolithic, Janisławice culture, Niemen culture, Funnel Beaker culture.

Jan ("Jasiu”) Kowalczyk was born in the Lublin countryside in 1918. He was a would-be student of naval construction at the Gdańsk University of Technology, a volunteer defender of Lublin in the famous September of 1939, a believer, gentle, kind and wise, a father with a tragic post-war history.

He learned archaeology in post-war Lublin, choosing to study the Neolithic, first on a regional scale, then on a wider one. A great expert in Neolithic pottery, a man who loved people, calm, rather withdrawn, not to say... shy. And this "quiet" man in 1969, in the 34th volume of Wiadomości Archeologiczne, published his habilitation thesis on the beginnings of the Neolithic period in Poland (Kowalczyk 1969). A rather analytical and traditional study, which is now out-of-date, but in one aspect, at least on the scale of Polish archaeology - revolutionary. The revolutionariness/exceptionalism of this work concerns... the idea of a "ceramic Mesolithic". This was a thesis not quite new in European archaeology, but in Poland of those times, it was.

The idea was paradoxical. After all, the earliest ceramics are/must be Neolithic, and the lack of ceramics means of course "Paleolithic/Mesolithic" attribution! That is how it was seen at this time.

The great Gordon V. Childe had denied such thinking at some point, questioning traditional paradigms and formulating new ones. He proposed a new definition of the Neolithic (farmers and stock herders), based on economic criteria, and per analogiam

a Institute of Archaeology, Cardinal Stefan Wyszyński University in Warsaw, I/3 Wóycickiego st., oI-938 Warsaw, Poland, e-mail: skkozlowski@op.pl ORCID: oooo-oooI-7374-6450 
of non-Neolithic/Mesolithic (hunters-gatherers). The consequence was the thesis about the possibility of existence of a preceramic Neolithic formation phase. At that time it was a revolutionary idea, but in the British prehistorian's reasoning it lacked its logical symmetry, that is, the complement 'from the other side'. After all, if the Neolithic could be "aceramic", i.e. defined not by means of a technical but an economic criterion, then probably the economically opposing Mesolithic, in some cases, could be "ceramic". Was this possible? A Ceramic Mesolithic? Well, just for the symmetry of a beautiful hypothesis.

After all as there is "bright", so there must be a "dark" as well, if something is big, something else must be small, when something is hot, something must be cold, if something was aceramic, something else should have been ceramic...

And it was Jan Kowalczyk who was reasoning in this way, following the British professor.

Almost no one in Poland cared for this idea, because the Polish archaeological 'establishment' at the time did not have the imagination of the modest researcher from Lublin.

The challenge had been thrown out... and it was as if forgotten - we had not grown up to his stature in those days. Today we are smarter.

Jan Kowalczyk wrote about the ceramic Mesolithic in his dissertation as follows: The Polish territories are situated in the passage zone of Europe, between its southern and northern parts. In the North, agriculture and stockbreeding appeared later than pottery and therefore that phase can be called "the ceramic Mesolithic" (Kowalczyk 1969: 67).

People read the work, a few reviews appeared, but the thesis did not meet acceptance in Polish archaeology, because it had gone beyond the logic of people sorting material in museums. In the mind of his contemporaries, everything that was earlyceramic, had to be by definition "Neolithic", and any microlithic flint material, which accompanied such an early "Neolithic" ceramic in the sands of the Polish Lowlands, obviously had to be "Mesolithic" The pottery sherds then went to the "Neolithic" museum shelf, and flint artefacts - to the "Mesolithic" one. And so it turned out that Poland had different "Neolithic"/ceramic cultures: "Comb", "Pit-and-Comb", "Pre-Finnish", "Baltic", ultimately "Niemen" [Neman] pottery cultures, the latter devoid of a flint industry.

This resulted from a deep misunderstanding of the matter. It was then assumed that Neolithic flint specimens should be dimensionally "large", "polished", and should have flat surface retouches, possibly "retouch in form of gutter", and such flints were not found in the company of "Pit-Comb pottery".

And the circle of misunderstanding was closed. Well, maybe not for everyone, I had a shy suspicion that the assignments of museum materials was incorrect in such cases, and today, along with Marek Nowak, I am sure about it. Here I refer to our latest book on this subject (Kozłowski and Nowak, in print). 
Also Elżbieta Kempisty in the 1970s, abandoned the term "Neolithic" for "paraNeolithic", quietly accepting Kowalczyk's thesis.

Of course, understanding of the issues and possibilities of accepting the term "ceramic Mesolithic" are today in Poland, but also in Europe, more clear than in the time of Kowalczyk's publication, because we have in our country a whole series of sites being excavated or properly surface explored that are confirming the thesis of the late researcher.

Below I present basic information on these sites, first considering the sites of Central and Eastern Poland, characterised by flint inventories in the style of "Janisławician" tradition.

At the beginning, I place the stratified features in which ceramics have co-occurred in cultural layers with a late-Mesolithic flint industry. These are multilayer sites, "sealed" and well-dated by series of ${ }_{14} \mathrm{C}$ determinations. Taking into account all possible methodological objections (doubts about post-depositional processes within and between layers), their homogeneity cannot be questioned. Stratified sites are situated near water reservoirs, which has led to the development of expanded coastal stratigraphies.

I. Grądy-Woniecko, Zambrów district

The site was examined by Krzysztof Burek, and published by Adam Wawrusiewicz with colleagues (Wawrusiewicz et al. 20I8). Over a large area was found a partly stratigraphically sealed (!), deposit of late-Mesolithic flint material with Neman ceramics in its subsequent, chronological variants. Flints of "Neolithic" type (definition see above) were not found. $\mathrm{I}_{4} \mathrm{C}$ dating, made among others samples of human bones and carbonized deposit on ceramic, place all material within the fourth millennium BC.

2. Dudka and Szczepanki, Giżycko district

Two multi-layered sites excavated by Witold Gumiński provided Zedmar ceramics and numerous flint artefacts (Gumiński 1997; 1999; 2004). Contrary to the opinion of the explorer, these were typical items of Late Mesolithic Janisławice culture, which were accompanied by late triangular and heart-shaped arrowheads with surface retouch. There were also some pottery sherds of the Funnel Beaker culture (hereafter: FBC) as well as of the Brześć-Kujawski culture items.

3. The co-occurrence of the Janisławice material (and a few late arrowheads with a flat retouch) with the Neman pottery was also confirmed by the excavations by Hanna Więckowska, Zofia Sulgostowska and E. Kempisty in Sośnia (Kempisty and Więckowska 1983) and in Woźna Wieś, both sites in the Grajewo district (Kempisty and Sulgostowska 199I), as well as in Stacze, Ełk district (Kempisty 1984), by excavations of Andrzej Krzyszowski in Kuców, Bełchatów district with Linin-type pottery according to E. Kempisty (Krzyszowski 1995: 50-53), those of Piotr A. Olszewski 
in Korzecznik, Koło district (Olszewski 1987), of Piotr Mitura in Wola Raniżowska, Kolbuszowa district (Mitura 1994), and finally of Zygmunt Szmit in Czerwony Borek XXIV (Słochy Annopolskie), Siemiatycze district and in Hryniewicze Wielkie, Bielsk Podlaski district (Szmidt 1929), as well as those of Krzysztof Cyrek in Łykowe (Cyrek 1990) and of Ewa Niesiołowska in Osjaków (Niesiołowska 1971) - both sites in the Wielun district.

4. A few of the sites were excavated by Małgorzata Rybicka and Andrzej Pelisiak in Gostynin district (Rybicka 1995; Pelisiak and Rybicka 1998; material in the Archaeological and Ethnographic Museum in Łódź), on which has been stated the cooccurrence of the Neman and/or FBC (more often) pottery with Janisławice flint (plus macrolithic blades imported from the south). This material (devoid of slender microliths), was analysed and properly interpreted by Michał Dobrzyński in his $\mathrm{PhD}$ (Dobrzyński 20I4).

Where dating was obtained (Grądy-Woniecko, Dudka, Szczepanki, Korzecznik, Woźna Wieś, Sośnia, Gostynin Lake District), the material has to be placed within the IV and III millennia BC.

Correlation between FBC and Janisławician also occurred in Kuców, Bełchatów district (Krzyszowski 1995) and Baraki Stare, Stalowa Wola district (Libera and Tymczak 1990).

5. In the Podlaskie Museum in Białystok there are collections from AZP (Polish Archaeological Record) research. Adam Wawrusiewicz shared with me a selection of 30 collections containing pottery of the Neman type. In almost all cases, flint material of Janisławician type had accompanied these sherds.

6. Similar flint material with Neman pottery, collected by Jerzy Siemaszko and Jerzy Brzozowski from the lower reaches of the Lega River, is located in the District Museum in Suwałki.

7. Collections of the State Archaeological Museum in Warsaw.

Especially at the confluence of the Vistula and Bug-Narew rivers, as well as on the Narew, Elżbieta Kempisty indicates pottery of the Neman type and less numerous ceramics of the FBC (mainly collected by Stefan Krukowski), also in Linin style imitating Neolithic pottery. Pottery is accompanied exclusively by a flint industry of Janisławice type, published by Stefan K. Kozłowski (Kozłowski S. K. 1975).

8. The surface collections of Władysław Kasiński are kept in the Archaeological and Ethnographic Museum in Eódź and the depository of the Polish Academy of Sciences in Warsaw also present the same correlation.

9. Collections of Zygmunt Gloger at the Archaeological Museum in Cracow. The collections coming from the upper Narew are dominated by flint material of the Janisławician type, accompanied by pottery, mainly of the Neman type. 


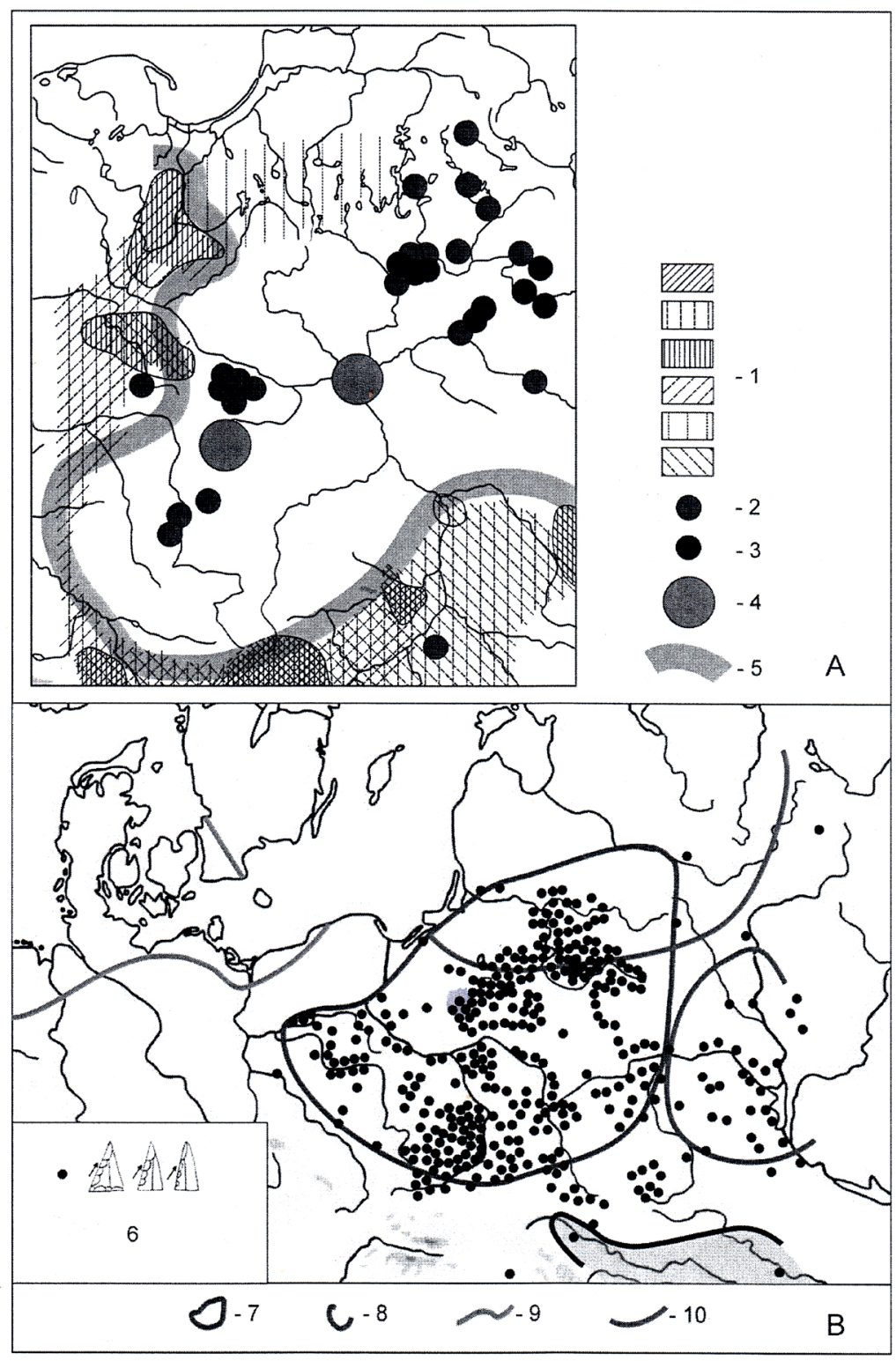

Fig. I. Ceramisation of the Mesolithic of Central and Eastern Poland (according to M. Nowak and S. K. Kozłowski): A - similitudes between the views of both researchers: M. Nowak and

S. K. Kozłowski: I - I. "Bandkeramiker”; 2. Mesolithic: 2 - excavated sites, 3 - systematic surface explorations, 4-old surface collections; 5 - Mesolithic-Neolithic border from the pre-Beaker period; B - Mesolithic ceramics: 6 - according to S. K.Kozłowski, 7 - according to M. Nowak; 8 - East Pripyat-river culture, 9 - Ertebølle culture, Io - Narva culture. 


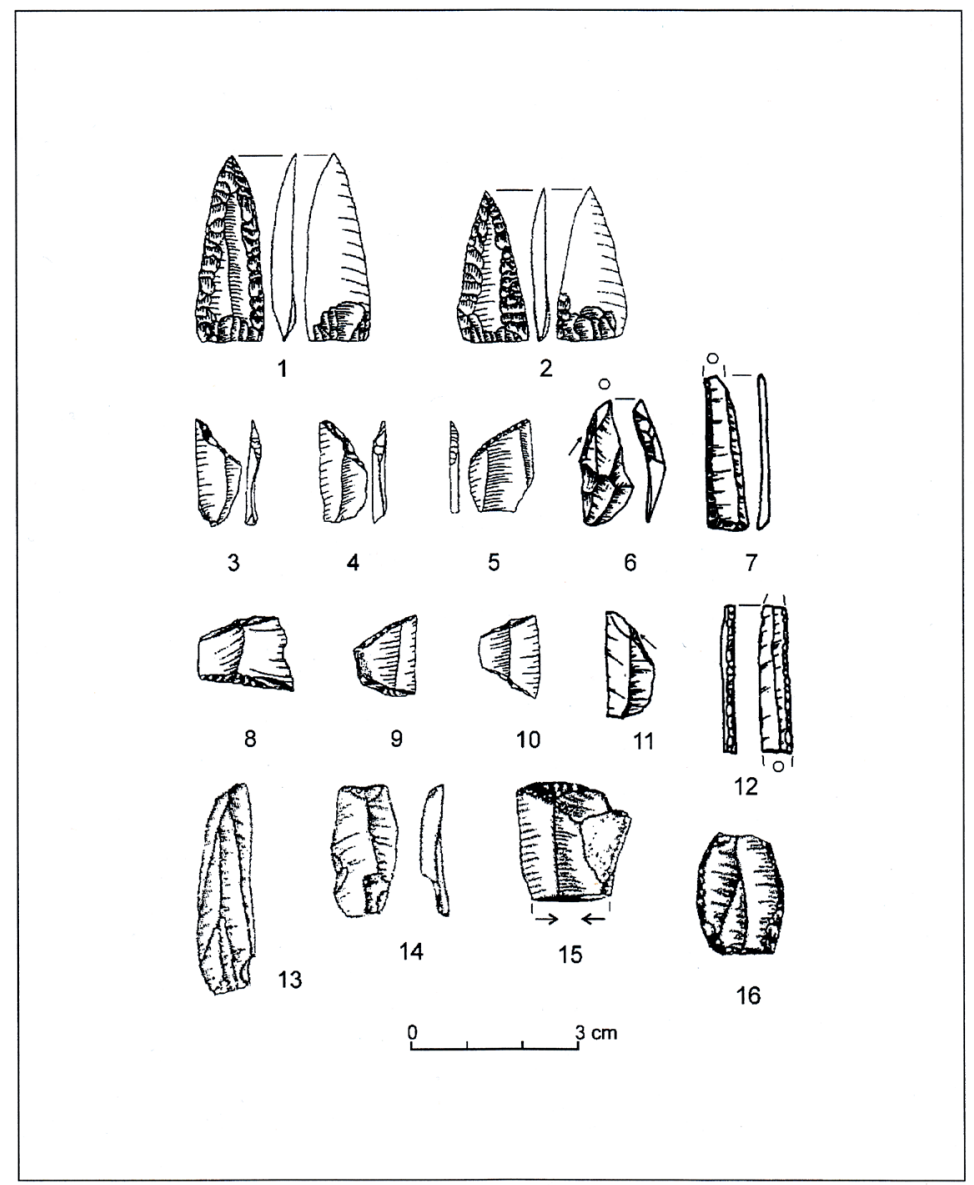

Fig. 2. Very late ceramisation of the Janisławician - Dudka and Szczepanki, Giżycko district; numbers 6, 7, II, I2 come from a context containing Zedmar pottery (according to Gumiński 1997; 2004).

\section{TIME AND TAXONOMY}

The sites and groups of sites described in this short catalogue, omitting less reliable, older collections from the surface (in State Archaeological Museum - mainly those of S. Krukowski, in Archaeological and Ethnographic Museum in Łódź - of W. Kasiński and in the Archaeological Museum in Cracow - of Z. Gloger), suggest in an unambiguous way the immanent relations of "forest"/para-Neolithic ceramics (mainly the fourth millennium BC and later): Neman, Zedmar, Linin - with the regional 


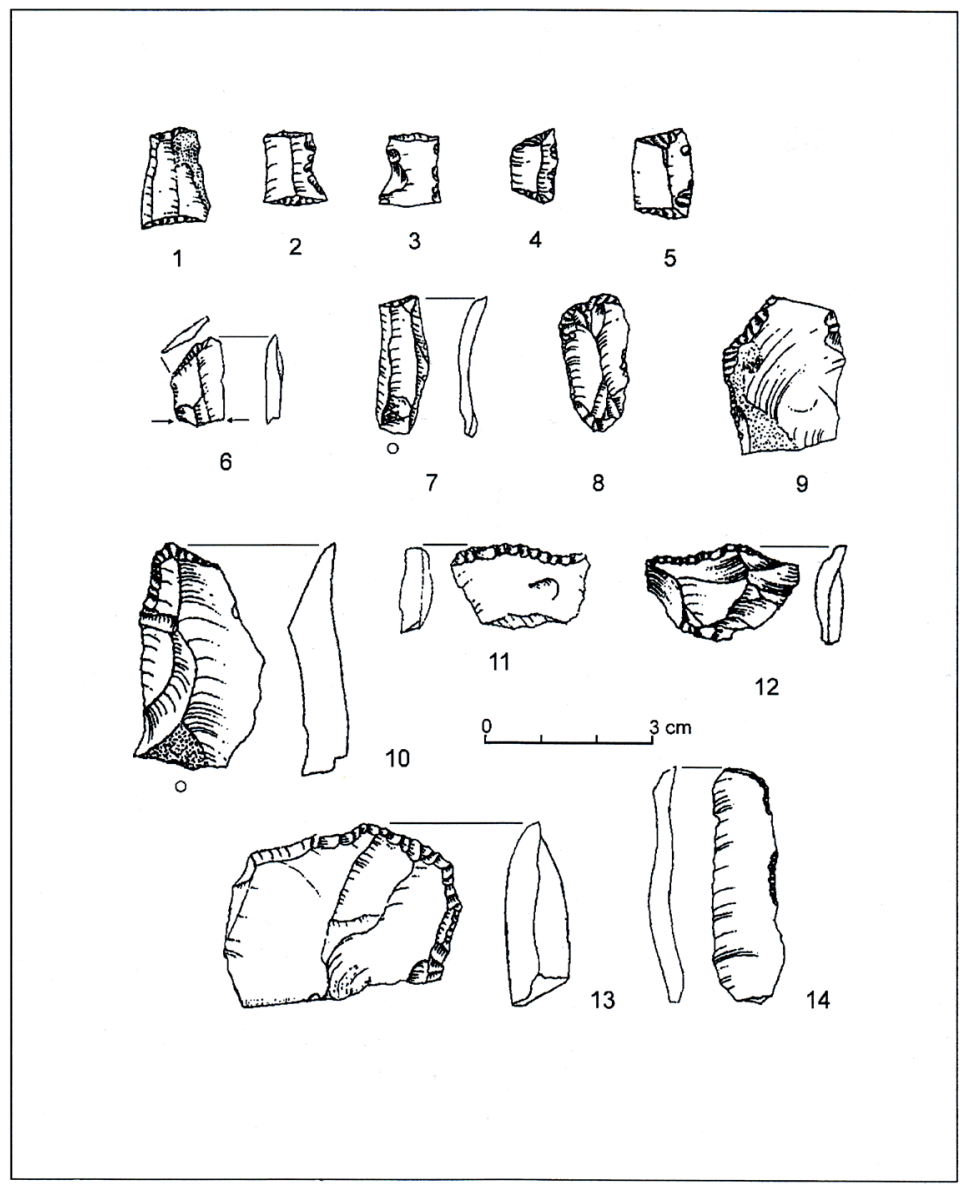

Fig. 3. Janisławician with Neman pottery - Łykowe, Wieluń district (according to Cyrek 1990).

Mesolithic industry - Janisławician, and on a larger scale of the country - with late Mesolithic.

We have the most data on this subject from Central and Eastern Poland, where such relationships are testified to by the stratified sites (Dudka and Szczepanki in stratigraphy with Zedmar pottery, and Janisławician at Grądy-Woniecko with Neman pottery), but also, methodically excavated sites (Sośnia, Woźna Wieś, Osjaków, Łykowe, Wola Raniżowska, Kuców, Baraki Stare, and others), and finally the sites from the Podlaskie Voievodeship and from the lower Lega River very methodically explored and recorded within the AZP (Polish Archaeological Record) project. 
30 Stefan Karol Koztowski

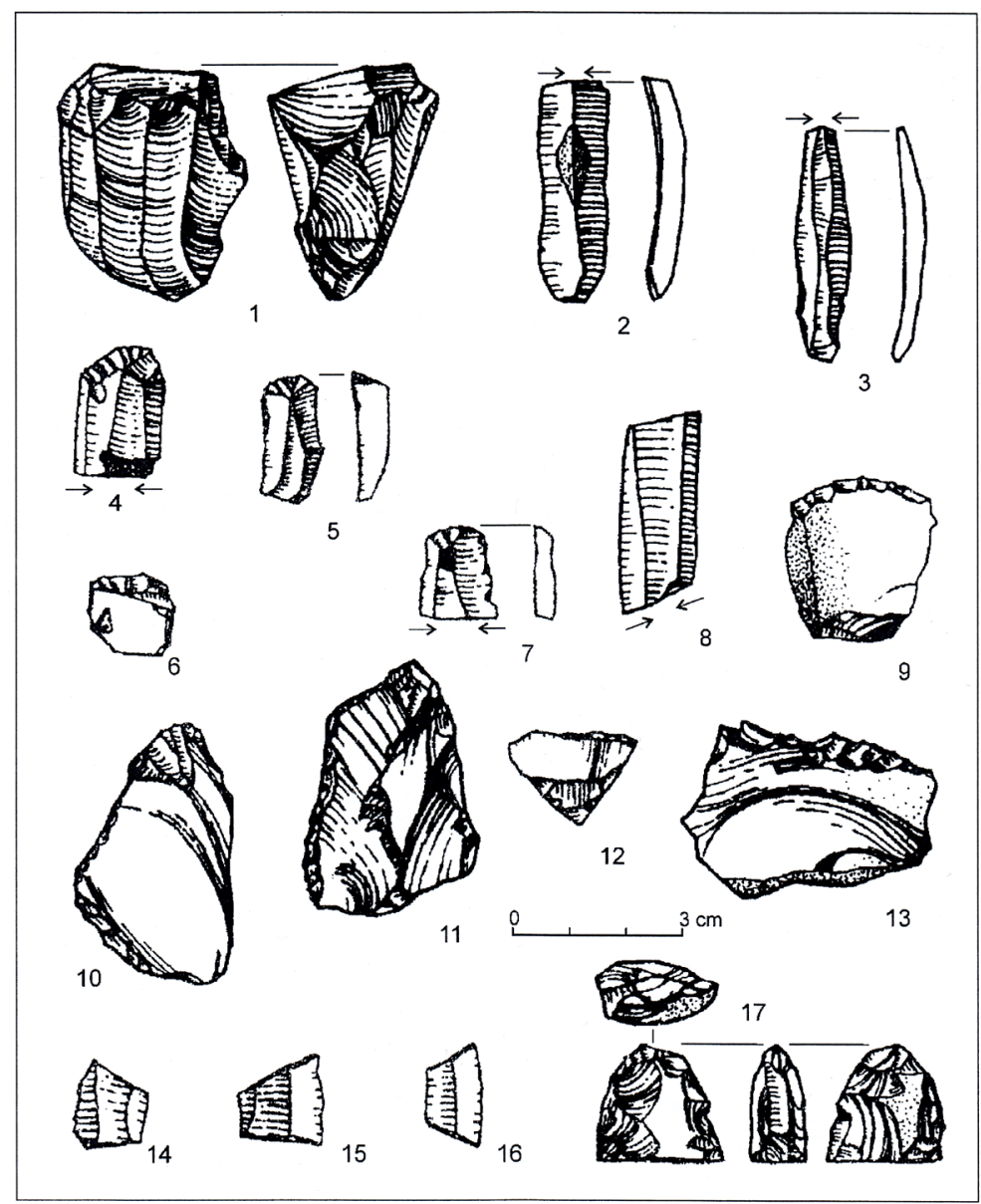

Fig. 4. Janisławician with FBC and Linin pottery - Kuców, Bełchatów district (according to Krzyszowski 1995).

Thus, the relationship between the Polish Janisławician and the "forest" pottery is unquestionable, even if not all of the evidence cited is entirely accurate. Finally, it is confirmed by Janisławice elements, signalled by Mihail Charnyauski from Belarus (Charnyauski [Чарняўскі] 1987; 1997a; 1997b; 1997c; 20II), as well as by single points of the Janisławice type from the Latvian Dvina River (there in the context of Narva pottery - materials in the National Museum of Latvian History in Riga) and 
Belarussian Berezina (materials of the Dnieper-Donets culture - data obtained from Russian colleagues).

There is also a cartographic argument for Polish territories: the territorial range of the Neman pottery in Poland, published by Bartosz Józwiak (2003, map 8), coincides with the range of Janisławice points, published by S. K. Kozłowski (1972; 1989).

To close the Janisławician case, two more pieces of information may be cited:

- the descriptions above prove the chronological parallelism of the Polish ceramic Mesolithic with the settlement of the Linear Pottery culture and of the LengyelPolgár complex in some areas of our country (among others, imports and imitations of Neolithic pottery at stratified Masurian sites).

- Janisławice flint elements, devoid of slender microliths, are encountered in some well excavated and documented FBC sites in the Polish Lowlands, outside the settlement area of the Linear Pottery culture (Gostynin Lake District and Eódź Upland) as well as in the Sandomierz Basin). We owe this important observation to, among others, Michał Dobrzyński (20I4). This researcher indicates the presence in the Gostynin-region sites of macrolithic blades imported from the south together with Janisławice material. So far, they have been deposited in museums on the "Neolithic" shelf. Today we know that our Professors were wrong.

We might mention here some similar observations, but for another late-Mesolithic tradition, in Western Poland (research by Michał Kobusiewicz, Zbigniew Bagniewski, Jolanta Ilkiewicz and Jacek Kabaciński), where together with the local late Mesolithic material occur:

- Ertebølle pottery: Dąbki, Sławno district in Pomerania (Ilkiewicz 1989; 1997; Kabaciński and Terberger 2009; Kabaciński et al. 2009; Kabaciński et al. eds 2015; Czekaj-Zastawny et al. 20II) and Chobielin, Nakło district in the Lubusz Land;

- FBC pottery: Dąbki in Pomerania (Kabaciński and Terberger 2009; Kabaciński et al. 2009; Kabaciński et al. eds 2015; Czekaj-Zastawny et al. 20II), DąbrowaKrępnica, Bolesławiec district in south-western Poland (Bagniewski 1979) and Chwalim (the upper layer), Zielona Góra district (Kobusiewicz I98I; Kobusiewicz and Kabaciński i993).

Mesolithic pottery is not, of course, a purely Polish phenomenon, this is only part of a larger pattern. For the European Lowland, we will mention the classic Ertebølle, the Dutch Swijsterband, the East Baltic Narva culture, the Finnish Sperrings, the ceramic phase of the Butovian on the Upper Volga and the South Bug (Boh)-Dniester phase of the Grebiennikian on the Dniester, we will not miss the Dnieper-Donets culture in Southern Russia and the East Pripyat culture in Eastern Belarus. And in the south they will be: a large part of the Balkan-Italian impresso ware circle, most probably 
French-Spanish cardial ware circle, or local, north-Italian ceramics such as Gaban, Vho and Fiorano.

Thus, it can be admitted that almost the entire continent, with the exception of the Balkan-Danube corridor (with the cultures of Starčevo-Kriş and Linear Pottery), has been "mesolitically" ceramised. It was the people of the Mesolithic who ceramised a large part of the continent, probably without any significant participation of those of the Neolithic.

Jasiu, so you were right more than 50 years ago, which was completely beyond the horizon of perception of your contemporaries. Today we admit it to you, because we have managed to prove it...

Translated by Andrzej Leligdowicz

\section{REFERENCES}

Bagniewski, Z. 1979. Problem związów ludności mezolitycznej i neolitycznej na terenie Polski południowozachodniej. In W. Wojciechowski (ed.), Poczatki neolityzacji Polski potudniowo-zachodniej, 2I-35. Wrocław.

Charnyauski, M. М. (Чарняўскі, М. М.) 1987. Kamenniy i bronzoviy veka Ponemanya i Podvinya. In G. V. Schtihov (ed.), Belorusskaya arheologiya: doslidzhenniya arheologov za godi Sovettskoy vlasti, 37-47. Minsk [Каменный и бронзовый века Понеманья и Подвинья. In Г. В. Штыхов (ed.), Белорусская археология:достижения археологов за годы Советской власти. Минск].

Charnyauski, М. М. (Чарняўскі, М. М.) 1997а. Nemanskaya kultura. In M. M. Charnyauski and A. G. Kalechic (eds), Kamenni i bronzovi vyaki, I45-162, 236-245. Minsk. Arhealogiya Belarusi. T. г. [Нёманская культура. In М. М. Чарняўскі, А. Г. Калечыц (eds), Каменны і бронзавы вякі. Мінск. Археалогія Беларусі. Т. 1.].

Charnyauski, М. М. (Чарняўскі, М. М.) 1997b. Narvenskaya kultura. In M. M. Charnyauski and A. G. Kalechic (eds), Kamenni i bronzovi vyaki, 190-206, 272-277. Minsk. Arhealogiya Belarusi. T. г. [Нарвенская культура. In M. М. Чарняўскі, А. Г. Калечыц (eds), Каменны і бронзавы вякі. Мінск. Археалогія Беларусі. Т. г.].

Charnyauski, M. М. (Чарняўскі, М. М.) г997с. Paunochna belaruskaya kultura. In M. M. Charnyauski and A. G. Kalechic (eds), Kamenni i bronzovi vyaki, 3II-330, 369-383. Minsk. Arhealogiya Belarusi. Т. г. [Паўночна беларуская культура. In M. М. Чарняўскі and А. Г. Калечыц (eds), Каменньь і бронзавы вякі. Мінск. Археалогія Беларусі. Т. г.].

Charnyauski, M. М. (Чарняўскі, М. М.) 20Ir. Nemanskaya nealitichnaya kultura v Belarusi: genezis i evalyucya [Нёманская неалітычная культура ў Беларусі: генезіс і эвалюцыя]. In U. Stankiewicz and A. Wawrusiewicz (eds), Na rubieży kultur. Badania nad okresem neolitu i wczesna epoka. brązu, 77-86. Białystok.

Cyrek, K. 1990. Ausgrabungen auf einer mesolithischen und neolithischen Fundstelle bei Łykowe in Mittelpolen. In P. M. Vermeersch and P. van Peer (eds), Contributions to the Mesolithic in Europe. Papers presented at the Fourth International Symposium "The Mesolithic in Europe", Leuven I9go, 28I-293. Leuven. Studia praehistorica Belgica 5. 
Czekaj-Zastawny, A., Kabaciński, J. and Terberger, T. 2oIr. Relacje łowiecko-zbierackich społeczności z Dąbek z kulturami neolitycznymi Europy Środkowej. In U. Stankiewicz and A. Wawrusiewicz (eds), Na rubieży kultur. Badania nad okresem neolitu i wczesna epoka brązu, s. I6I-I74. Białystok.

Dobrzyński, M. 20I4. Krzemieniarstwo kultury pucharów lejkowatych w centralnej Polsce. Unpublished $\mathrm{PhD}$ thesis, University of Rzeszów.

Gumiński, W. 1997. Cmentarzysko społeczności zbieracko-łowieckich w Dudce. In L. Kuźnicki (ed.), Dziatalność Naukowa PAN, 2I-22. Warszawa.

Gumiński, W. 1999. Środowisko przyrodnicze a tryb gospodarki i osadnictwa w mezolicie i paraneolicie na stanowisku Dudka w Krainie Wielkich Jezior Mazurskich. Archeologia Polski 44: 3I-74.

Gumiński, W. 2004. Szczepanki 8. Nowe stanowisko torfowe kultury Zedmar na Mazurach. Światowit 5 (46) [2003/B]: 53-I04, pl.: $15-38$.

Ilkiewicz, J. 1989. From Studies on Cultures of the 4th Millennium B.C. in the Central Part of the Polish Coastal Area. Przeglad Archeologiczny 36: 17-55.

Ilkiewicz, J. 1997. From Studies on Ertebølle Type Cultures in the Koszalinian Coastal area (Dąbki 9, Koszalin-Dzierżęcino 7). In D. Król (ed.), The Built Environment of Coast Areas During the Stone Age, 50-65. Gdańsk.

Józwiak, B. 2003. Spoteczności subneolitu wschodnioeuropejskiego na Niżu Polskim w międzyrzeczu Odry $i$ Wisty. Poznań.

Kabaciński, J., Hartz S., Raemaekers, D. C. M. and Terberger, T. (eds) 20I5. The Dąbki Site in Pomerania and the Neolithisation of the North European Lowlands (c. 5000-3000 cal BC). Rahden/Westf.

Kabaciński, J., Heinrich, D. and Terberger, T. 2009. Dąbki revisited: new evidence on the question of earliest cattle use in Pomerania. In S. McCartan, R. Schulting, G. Warren and P. Woodman (eds), Mesolithic Horizons. Papers presented at the Seventh International Conference on the Mesolithic in Europe, Belfast 2005, 548-555. Oxford.

Kabaciński, J. and Terberger, T. 2009. From Late Hunter-fishers to Early Farmers on the Pomeranian Coast. New research at Dąbki 9, Koszalin District. In J. M. Burdukiewicz, K. Cyrek, P. Dyczek and K. Szymczak (eds), Understanding the Past. Papers offered to Stefan K. Koztowski, 165-184. Warszawa.

Kempisty, E. 1984. Nowe materiały kultur paraneolitycznych na stanowisku I w Staczach, woj. suwalskie. Wiadomości Archeologiczne 49(I): 45-74.

Kempisty, E. and Sulgostowska, Z. 1991. Osadnictwo paleolityczne, mezolityczne i paraneolityczne w rejonie Woźnej Wsi, woj. tomżyńskie. Warszawa.

Kempisty, E. and Więckowska, H. 1983. Osadnictwo z epoki kamienia i wczesnej epoki brazu na stanowisku I w Sośni, woj. tomżyńskie. Wrocław.

Kobusiewicz, M. 1981. Ausgrabungen auf einer mesolithischen und neolithischen Fundstelle bei Chwalim, Westpolen. Veröffentlichungen des Museums für Ur-und Frühgeschichte Potsdam I4/I5: 337-342.

Kobusiewicz, M. and Kabaciński, J. 1993. Chwalim. Subboreal hunter-gatherers of the Polish Plain. Poznań.

Kowalczyk, J. 1969. Początki neolitu na ziemiach polskich. Wiadomości Archeologiczne 34(I): 3-69.

Kozłowski, J. K and Kozłowski, S. K. 1977. Epoka kamienia na ziemiach polskich. Warszawa.

Kozłowski, S. K. 1972. Pradzieje ziem polskich od IX do V tysiąclecia p.n.e. Warszawa.

Kozłowski, S. K. 1975. Ważniejsze mezolityczne materiały powierzchniowe z terenu Warszawy i woj. warszawskiego. Światowit 34: I49-I88.

Kozłowski, S. K. 1989. Mesolithic in Poland, a New Approach. Warszawa.

Kozłowski, S. K. 2009. Thinking Mesolithic. Oxford.

Kozłowski, S. K. and Nowak, M. In print. I przyszli ludzie zza Gór Wysokich. Rzeszów.

Krzyszowski, A. 1995. Osadnictwo neolityczne na stanowisku I w Kucowie, gm. Kleszczów, woj. Piotrków Trybunalski. Prace i Materiaty Muzeum Archeologicznego w Eodzi. Seria Archeologiczna 37-38 (I99I1992): $25-63$ 
34 Stefan Karol Koztowski

Libera, J. and Tymczak, D. 1990. Późnomezolityczne stanowisko I3 w Barakach Starych, gm. Zaklików, woj. Tarnobrzeg. Sprawozdania Archeologiczne 42: 69-93.

Mitura, P. 1994. Obozowisko ludności subneolitycznej na stanowisku 22 w Woli Raniżowskiej-Stecach, gm. Raniżów, woj. Rzeszów. Sprawozdania Archeologiczne 46: 13-29.

Niesiołowska-Śreniowska, E. 197I. Sprawozdanie z dotychczasowych badań na stanowisku 3 w Osjakowie, pow. Wieluń. Prace i Materiaty Muzeum Archeologicznego i Etnograficznego w Eodzi. Seria Archeologiczna I8: 77-92.

Olszewski, P. A. 1987. Osadnictwo epimezolityczne w Korzeczniku, woj. koninskie, stanowisko 6/7. Inowrocław.

Pelisiak, A. and Rybicka, M. 1998. Ceramika neolityczna z wielokulturowej osady w Gościążu, st. I2, woj. Włocławskie. Prace i Materiaty Muzeum Archeologicznego i Etnograficznego w Eodzi, Seria Archeologiczna 39: 207-220.

Rybicka, M. 1995. Materiały ceramiczne kultury pucharów lejkowatych i niemeńskiej ze stanowiska 5 w Grabinie, gm. Łąck, woj. płockie ( $\mathrm{Z}$ badań nad chronologią osadnictwa neolitycznego na Pojezierzu Gostynińskim). Prace i Materiaty Muzeum Archeologicznego i Etnograficznego w Eodzi, Seria Archeologiczna 37-38: 7-I8.

Szmit, Z. 1929. Badania osadnictwa epoki kamiennej na Podlasiu. Wiadomości Archeologiczne I0: 36-II8.

Wawrusiewicz, A., Kalicki, T., Przeździecki, M., Fraczek, M. and Manasterski, D. 2017. Grady-Woniecko. Ostatni towcy-zbieracze znad środkowej Narwi. Białystok. 